\title{
Synthesis and functional activity of tRNAs labeled with fluorescent hydrazides in the D-loop
}

\author{
DONGLI PAN, ${ }^{1}$ HAIOU QIN, and BARRY S. COOPERMAN \\ Department of Chemistry, University of Pennsylvania, Philadelphia, Pennsylvania 19104-6323, USA
}

\begin{abstract}
We describe an optimized procedure for replacing the dihydrouridine residues of charged tRNAs with Cy3 and Cy5 dyes linked to a hydrazide group, and demonstrate that the labeled molecules are functional in ribosomal activities including $30 \mathrm{~S}$ initiation complex formation, EF-Tu-dependent binding to the ribosome, translocation, and polypeptide synthesis. This procedure should be straightforwardly generalizable to the incorporation of other hydrazide-linked fluorophores into tRNA or other dihydrouridine-containing RNAs. In addition, we use a rapid turnover FRET experiment, measuring energy transfer between Cy5-labeled tRNA ${ }^{\text {fMet }}$ and Cy3-labeled fMetPhe-tRNA ${ }^{\text {Phe }}$, to obtain direct evidence supporting the hypothesis that the early steps of translocation involve movements of the flexible 3 '-single-stranded regions of the tRNAs, with the considerable increase in the distance separating the two tRNA tertiary cores occurring later in the process.
\end{abstract}

Keywords: tRNA; dihydrouridine; Cy3; Cy5; hydrazide; FRET; translocation

\section{INTRODUCTION}

Fluorescently labeled tRNAs have been widely used to study tRNA movement on the ribosome during various steps of the initiation and elongation cycles (Rodnina et al. 1994; Rodnina et al. 1997; Pape et al. 1998; Savelsbergh et al. 2003; Blanchard et al. 2004a,b; Pan et al. 2006, 2007; Grigoriadou et al. 2007a,b; Kothe and Rodnina 2007; Munro et al. 2007; Fei et al. 2008). For these studies, fluorescent groups have been introduced via (1) derivatization of the amino acid with which the tRNA is charged: either the $\alpha$-amino group of Met (initiator tRNA) (McIntosh et al. 2000) or the $\varepsilon$-amino group of Lys (Woolhead et al. 2004); (2) alkylation of $8-s^{4} U$ (Blanchard et al. 2004a,b; Bieling et al. 2006; Munro et al. 2007; Fei et al. 2008); (3) acylation of 47-acp ${ }^{3} \mathrm{U}$ (Blanchard et al. 2004a,b; Munro et al. 2007); (4) selective removal at acid $\mathrm{pH}$ of the wybutine base and its replacement by various nucleophiles (Schleich et al. 1978); and (5) selective reduction of dihydroU at several positions in the D-loop, with replacement of the reduced

\footnotetext{
${ }^{1}$ Present address: Department of Biological Chemistry and Molecular Pharmacology, Harvard University School of Medicine, Boston, MA 02115, USA.

Reprint requests: Barry S. Cooperman, University of Pennsylvania, Department of Chemistry, Philadelphia, PA 19104-6323, USA; e-mail: cooprman@pobox.upenn.edu; fax: (215) 898-2037.

Article published online ahead of print. Article and publication date are at http://www.rnajournal.org/cgi/doi/10.1261/rna.1257509.
}

product by a reactive group having the general structure $\mathrm{RNH}_{2}$ (Fig. 1C; Wintermeyer and Zachau 1979; Rodnina et al. 1994; Rodnina et al. 1997; Pape et al. 1998; Savelsbergh et al. 2003; Pan et al. 2006, 2007; Grigoriadou et al. 2007a,b; Kothe and Rodnina 2007). The latter approach, which we pursue in the work reported herein, is particularly attractive, since not only do almost all tRNAs contain dihydroU, but also introduction of fluorescent dyes into the D-loop can be carried out without impairing the ability of tRNAs to interact with the ribosome (Pape et al. 1998; Savelsbergh et al. 2003; Betteridge et al. 2007; Grigoriadou et al. 2007a,b; Pan et al. 2007). Only the $8-\mathrm{s}^{4} \mathrm{U}$ offers a comparably general approach to tRNA labeling, but we have found that fluorophore labeling of elongator tRNAs at this position severely reduces EF-Tu-dependent aa-tRNA binding to the ribosome (D. Cabral, pers. comm.).

Recent work has demonstrated the utility of singlemolecule detection of fluorescent tRNAs in elucidating mechanistic details of tRNA interactions with the ribosome (Blanchard et al. 2004a,b; Lee et al. 2007; Munro et al. 2007; Fei et al. 2008). Although Zachau and his coworkers and others had demonstrated that several $\mathrm{RNH}_{2}$ compounds (e.g., amines, hydrazines, hydrazides) could, in principle, be used to replace dihydroU within tRNA (Wintermeyer and Zachau 1974, 1979; Wintermeyer et al. 1979; Yang and Söll 1974), as a practical manner, most studies of tRNA-ribosome interaction using this approach have focused virtually exclusively on proflavin-labeled 
A
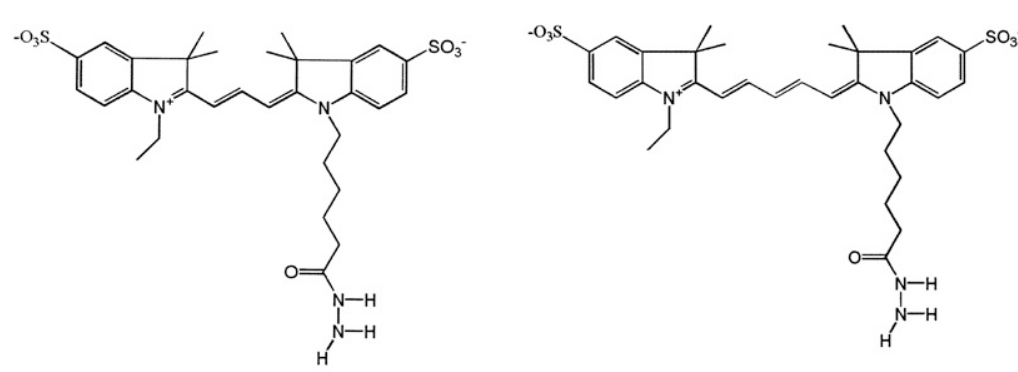

C

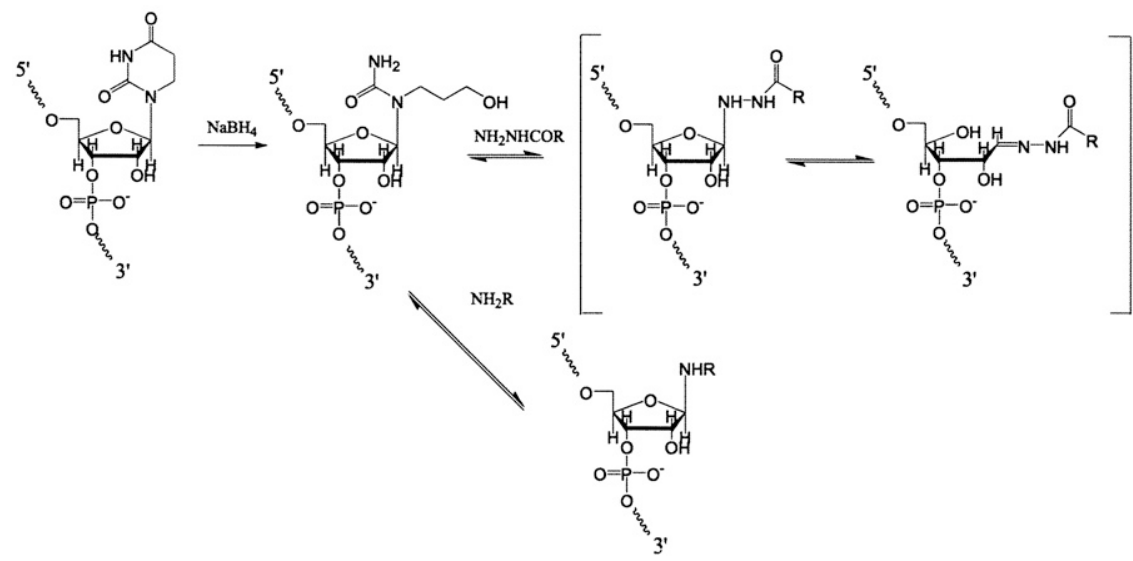

FIGURE 1. $(A, B)$ Structures of Cy3-hydrazide and Cy5-hydrazide. $(C)$ The labeling scheme. Reductive cleavage of dihydrouridine by sodium borohydride, yielding 3-ureidopropanol, has been described by Cerutti and Miller (1967).

tRNA (Rodnina et al. 1994, 1997; Pape et al. 1998; Savelsbergh et al. 2003; Pan et al. 2006, 2007; Grigoriadou et al. 2007a,b; Kothe and Rodnina 2007). However, proflavin is rapidly photobleached, making it unsuitable for single-molecule experiments. To overcome this limitation we recently described derivatization of tRNA with rhodamine 110 (Betteridge et al. 2007) which, while having two symmetrically placed primary amines and other structural features similar to proflavin, is useful for single-molecule studies. Indeed, single-molecule work is underway in our laboratory using rhodamine 110-labeled tRNAs (data not shown).

Future single-molecule experiments will require tRNAs labeled with a variety of different fluorophores. To meet this need, we here describe an optimized procedure for synthesizing charged, labeled tRNAs via dihydroU reduction that contain high stoichiometries of either Cy3hydrazide or Cy5-hydrazide (Fig. 1) and demonstrate the functionality of such derivatives in ribosome-catalyzed reactions. As there are several other dyes that, like Cy3 and Cy5, are suitable for single-molecule work and are commercially available as hydrazide derivatives, this procedure should be suitable for making the desired suite of labeled tRNAs.

\section{RESULTS AND DISCUSSION}

\section{Substituting Cy hydrazides for $D$ residues in tRNAs}

Yeast $\mathrm{tRNA}^{\text {Phe }}$ has $\mathrm{D}$ residues at positions 16 and 17. Labeling of yeast tRNA $^{\text {Phe }}$ with Cy3 hydrazide was initially attempted by using the two-step procedure previously employed to label the $\mathrm{D}$ positions with proflavin or rhodamine 110 (Wintermeyer and Zachau 1979; Betteridge et al. 2007), in which reduction of the $\mathrm{D}$ residue by treatment with $\mathrm{NaBH}_{4}$ at neutral $\mathrm{pH}$ and room temperature, forming $\mathrm{tRNA}^{\mathrm{Phe}}$ (red), is followed by reaction with $2 \mathrm{mM}$ dye at $\mathrm{pH} 3,37^{\circ} \mathrm{C}$ for $45 \mathrm{~min}$ to $90 \mathrm{~min}$. However, utilization of these conditions led to very poor incorporation of dye $(<0.05$ Cy3/tRNA), compared with essentially stoichiometric incorporation of proflavin (1.7-2.0 prf/tRNA) (Pan et al. 2007) and considerably higher incorporation of rhodamine 110 (1.0/ tRNA) (Betteridge et al. 2007).

A systematic study of dye uptake as a function of $\mathrm{pH}$ and time of incubation (Fig. 2) led to the choice of $\mathrm{pH} 3.7$ and $2 \mathrm{~h}$ as optimal. Under these conditions, dye incorporation increased linearly with dye concentration in the range 0.5-4 mM, reaching $0.15 \mathrm{Cy} 3 / \mathrm{tRNA}$ at $4 \mathrm{mM}$. Further increasing Cy3 hydrazide concentration to $40 \mathrm{mM}$ yielded an uptake of $1.2-1.3 \mathrm{Cy} / \mathrm{tRNA}^{\text {Phe }}$. Application of the high concentration procedure to other tRNAs and to substituting Cy5 hydrazide for Cy3 hydrazide afforded the following results: $0.94 \mathrm{Cy} 3 /$ Escherichia coli $\mathrm{tRNA}^{\mathrm{Arg}}$ (2 D residues); 0.39 Cy5/E. coli $\mathrm{tRNA}^{\mathrm{fMet}}$ (1 D residue).

In addition to $\mathrm{D}$ residues, yeast $\mathrm{tRNA}{ }^{\text {Phe }}$ has a wybutine base at position 37. This base can be excised and replaced with primary amine nucleophiles attached to dyes by prolonged incubation at $\mathrm{pH} 2.9$ without the need for $\mathrm{NaBH}_{4}$ reduction, although the overall reaction was found to proceed more slowly than substitution at the $\mathrm{D}$ positions following $\mathrm{NaBH}_{4}$ reduction (Thiebe and Zachau 1968; Wintermeyer and Zachau 1971; Schleich et al. 1978; Wintermeyer and Zachau 1979). To test whether substitution at position 37 was competitive with substitution at the $\mathrm{D}$ positions under the optimized conditions described above, we made a direct comparison of dye incorporation when the $\mathrm{NaBH}_{4}$ step is omitted vs. when it is included (Fig. 3). Consistent with the earlier work, we find values of dye incorporation of $\leq 0.08$ and $1.2 \mathrm{Cy} 3 / \mathrm{tRNA}$, respectively, demonstrating that virtually all of the dye is incorporated into the $\mathrm{D}$ positions when the $\mathrm{NaBH}_{4}$ step is included. 
A

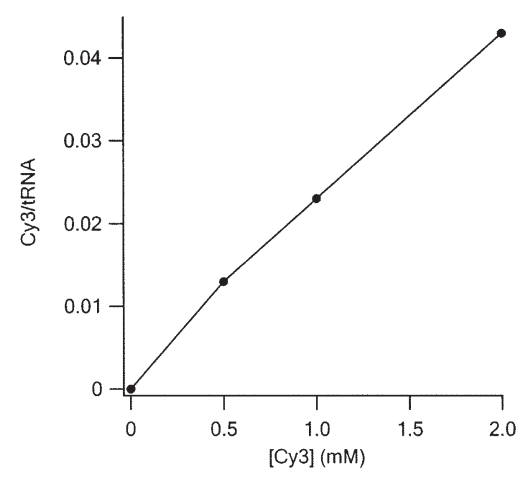

B

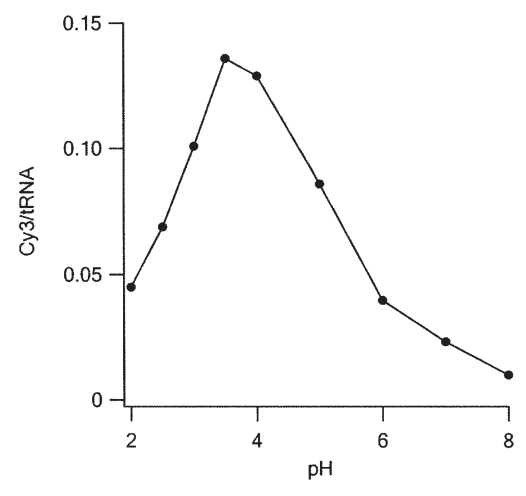

$\mathrm{C}$

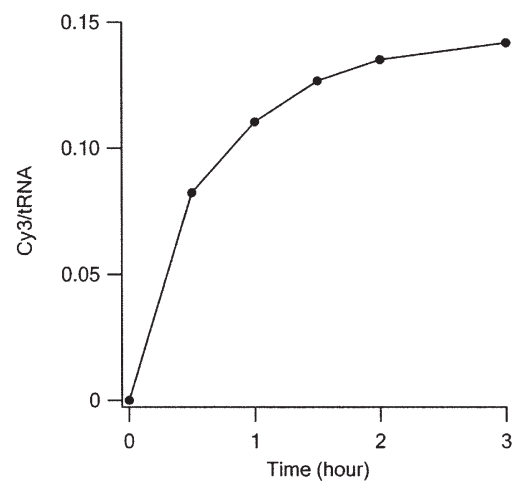

FIGURE 2. Optimization of labeling conditions. In each reaction 200 pmol of tRNA ${ }^{\text {Phe }}$ (red) was mixed with Cy3 in $100 \mu \mathrm{L}$ of $0.1 \mathrm{M}$ buffer at $37^{\circ} \mathrm{C}$. Reaction was stopped by raising $\mathrm{pH}$ to 7.5 . Excess dye was removed by two phenol extractions and two ethanol precipitations prior to $A_{550 \mathrm{~nm}}$ measurements. $(A)$ Dye concentration dependence. $\mathrm{pH}=3.0(\mathrm{Na}$ formate), incubation time, $1 \mathrm{~h}(B) \mathrm{pH}$ dependence. $[\mathrm{Cy} 3]=4 \mathrm{mM}$, incubation time $2 \mathrm{~h} \mathrm{Na}$ formate $(\mathrm{pH}<4)$, Na acetate $(\mathrm{pH} 4$ and 5), or $\mathrm{Na}$ phosphate buffer $(\mathrm{pH} \geq 6)$. (C) Time dependence. $[\mathrm{Cy} 3]=4 \mathrm{mM}$, pH 3.7 .

\section{Optimizing the charging of Cy3-labeled Phe-tRNA ${ }^{\text {Phe }}$}

Synthesis of charged, Cy3-labeled tRNA ${ }^{\text {Phe }}$ for use in functional studies may be considered to be a three-step procedure, involving $\mathrm{NaBH}_{4}$ reduction, labeling with Cy3 hydrazide, and charging by Phe-RS. Since reduction must precede labeling, there are three options for how these steps are sequenced: (1) charging-reduction-labeling; (2) reduction-labeling-charging; or (3) reduction-charginglabeling. Option 1 gives poor results, because of the high lability of Phe-tRNA ${ }^{\text {Phe }}$ toward $\mathrm{NaBH}_{4}$ treatment, which in our hands results in a $90 \%$ loss of Phe from the tRNA. Option 2 is also nonoptimal, because Cy3-labeled tRNA ${ }^{\text {Phe }}$ is less efficiently charged by Phe-RS under standard conditions than unlabeled tRNA ${ }^{\text {Phe }}$. For example, tRNA ${ }^{\text {Phe }}$ containing 1.3 Cy3s charges to a level of 480 pmol Phe/ $\mathrm{A}_{260}$, approximately twofold lower than the level of $\sim 900$ pmol Phe/ $\mathrm{A}_{260}$ obtained with unlabeled tRNA ${ }^{\text {Phe }}$.

The best results were obtained with option 3. In our optimized procedure, the reduction and charging steps were followed by RP-HPLC to separate charged from uncharged material (Fig. 4A), and the charged fraction was labeled with $40 \mathrm{mM}$ Cy3 hydrazide at $\mathrm{pH} 3.7$ as described above. The final material was subject to FPLC (Fig. 4B), leading to a major fraction, denoted PhetRNA $^{\text {Phe }}(\mathrm{Cy} 3)$, containing 1.0 Cy3/tRNA ${ }^{\text {Phe }}$ and charged to a level of $1190 \mathrm{pmol}$ Phe $/ \mathrm{A}_{260}$. Here, the choice of $\mathrm{pH} 6.0$ for the eluting buffer is critical, since higher $\mathrm{pH}$ leads to loss of Phe, whereas lower pH leads to loss of Cy3 (Fig. 4C).

Some synthetases may be less affected by Cy dye substitution in the D-loop than Phe-RS, allowing charging to follow labeling (option 2). In fact, this procedure was employed in preparing the Cy5-labeled fMet-tRNA ${ }^{\text {fMet }}$ used in the experiments reported below. Here the RPHPLC step was omitted and FPLC afforded a partially purified material denoted fMet-tRNA ${ }^{\mathrm{fMet}}(\mathrm{Cy} 5)$, containing $0.75 \mathrm{Cy} 5 / \mathrm{tRNA}^{\mathrm{fMet}}$ and charged to a level of $590 \mathrm{pmol}$ $\mathrm{fMet} / \mathrm{A}_{260}$. Control experiments showed that both options 2 and 3 lead to similar extents of charging.

The observation that $\mathrm{pH}$ 3.7, which is optimal for reduced tRNA ${ }^{\text {Phe }}$ labeling by $\mathrm{Cy} 3$ (Fig. 2B), would lead to unacceptable loss of $\mathrm{Cy} 3$ on isolation of $\mathrm{Cy} 3$-labeled

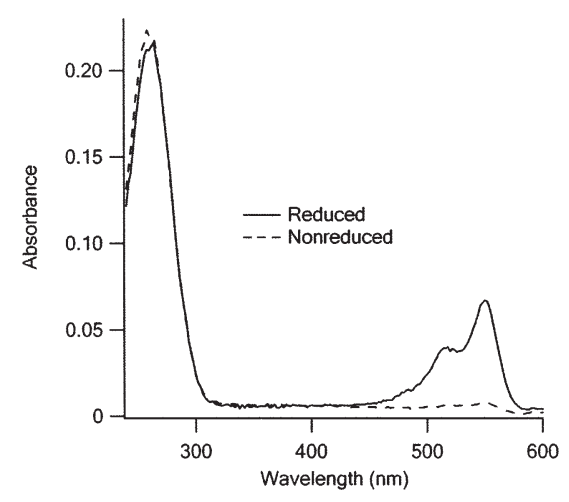

FIGURE 3. Dye incorporation is strongly dependent on $\mathrm{NaBH}_{4}$ reduction. A total of $400 \mathrm{pmol}$ of either $\mathrm{tRNA}^{\text {Phe }}$ (red) or untreated tRNA $^{\text {Phe }}$ was treated with Cy3 using the standard labeling protocol (Materials and Methods). Peaks at 260 and $550 \mathrm{~nm}$ correspond to the absorption of tRNA ${ }^{\text {Phe }}$ and $\mathrm{Cy} 3$, respectively. 


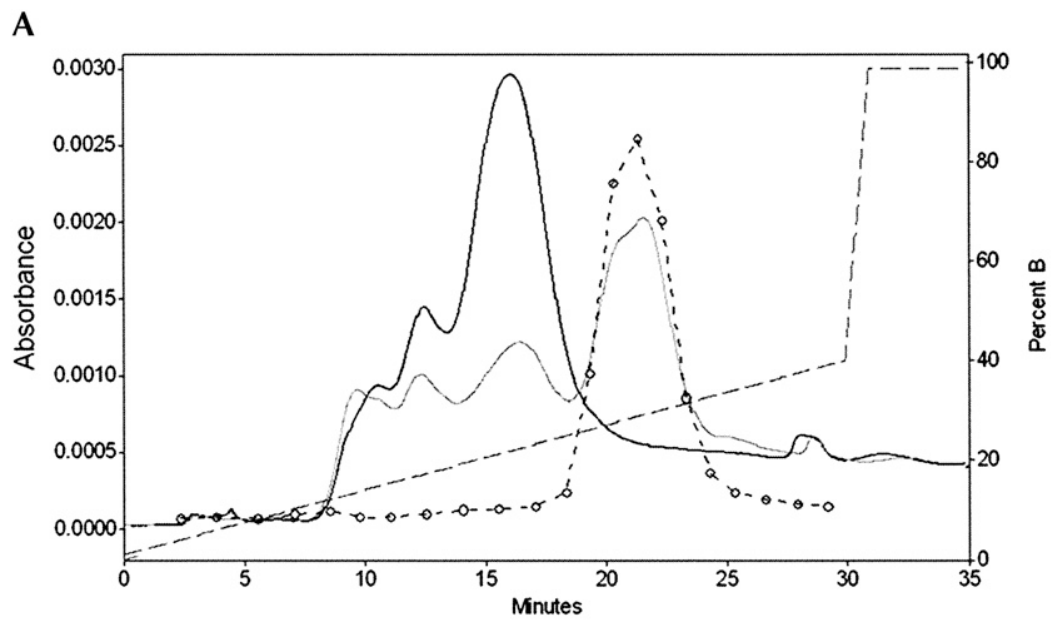

B

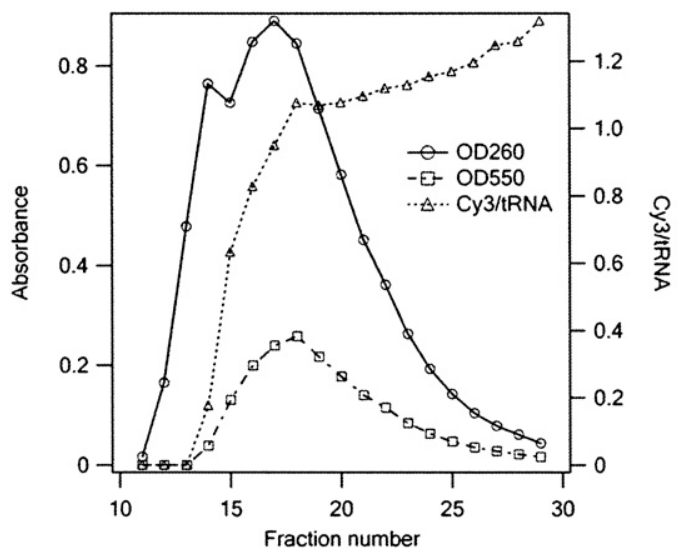

C

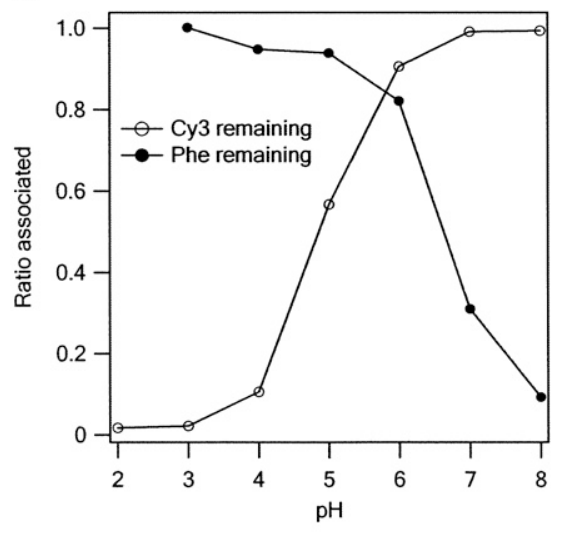

FIGURE 4. Chromatographic purifications of $\mathrm{tRNA}^{\text {Phe }}$ s. (A) Phenyl-RP-HPLC resolution of Phe-tRNA ${ }^{\text {Phe }}$ (red) from tRNA ${ }^{\text {Phe }}$ (red). Gray and black solid lines are chromatographs of unpurified $\left[{ }^{3} \mathrm{H}\right]-\mathrm{Phe}-\mathrm{tRNA}{ }^{\text {Phe }}$ and tRNA ${ }^{\text {Phe }}$ samples, respectively. Dashed line with circles shows $\left[{ }^{3} \mathrm{H}\right]$ counts of $\left[{ }^{3} \mathrm{H}\right]$-Phe-tRNA ${ }^{\text {Phe }}$ fractions. Dashed line alone shows the gradient. (B) Purification of Phe-tRNA ${ }^{\text {Phe }}($ Cy3) on an FPLC MonoQ column following labeling of Phe-tRNA ${ }^{\text {Phe }}$ (red), fractions 18-26 in A with Cy3-hydrazide. The rise in Cy3/tRNA ratio in the later fractions is due to small amounts of doubly labeled tRNA. (C) Retention of $\left[{ }^{3} \mathrm{H}\right]$-Phe and Cy3 with tRNA ${ }^{\text {Phe }}$ following incubation of $\left[{ }^{3} \mathrm{H}\right]-\mathrm{Phe}^{\mathrm{P}} \mathrm{tRNA}{ }^{\mathrm{Phe}}(\mathrm{Cy} 3)$ at $37^{\circ} \mathrm{C}$ for $2 \mathrm{~h}$ at various $\mathrm{pH}$ values. $\mathrm{Cy} 3$ content and $\left[{ }^{3} \mathrm{H}\right]$-Phe content were determined following ethanol precipitation and TCA precipitation, respectively. Buffers were the same as in Figure 2B.

tRNA $^{\text {Phe }}$ (Fig. 4C) is readily explainable. Raising the concentration of hydrazide shifts the equilibrium shown in Figure $1 \mathrm{C}$ in the direction of hydrazide adduct formation, consistent with our results, and the weakly acidic $\mathrm{pH}$ optimum for the rate of hydrazide adduct formation is in accord with results published for similar reactions (Cordes and Jencks 1962; Jencks 1964; Levrand et al. 2007). On the other hand, isolation of Cy3-labeled tRNA must be carried out under conditions which minimize hydrolysis of the hydrazide adduct, which is also acid catalyzed, mandating the use of a higher $\mathrm{pH}$ for this step (Cordes and Jencks 1962; Jencks 1964; Levrand et al. 2007).

Finally, it should be noted that many tRNAs contain two (as is the case for yeast tRNA $^{\text {Phe }}$ ) or even three dihydrouridine residues in the D-loop region. Thus, a sample containing one Cy dye/tRNA, as in the present case, might be heterogeneous, with labeling spread over more than one position. Such heterogeneity could be problematic for some kinds of single-molecule investigations, and might require the use of high resolution HPLC approaches to resolve different positional labeling isomers.

\section{Functional assays}

Formation of 305 initiation complex (30SIC)

The 30SIC consists of a 30 S subunit containing bound mRNA, charged and formylated initiator tRNA (fMettRNA $^{\mathrm{fMet}}$ ), and initiation factors IF1, IF2, and IF3. We have shown that the rate of 30SIC formation can be monitored by changes in fluorescence on ligand binding to the $30 \mathrm{~S}$ subunit, using either a proflavin derivative of $\mathrm{fMet}^{-\mathrm{tRNA}} \mathrm{fMet}^{\mathrm{f}}$, fMet-tRNA ${ }^{\mathrm{fMet}}$ (prf) (Grigoriadou et al. 
2007a,b), or a coumarin (Grigoriadou et al. 2007a) or Cy3 (H. Qin, C. Grigoriadou, and B.S. Cooperman, unpubl.) derivative of IF2. Here, using fMet-tRNA ${ }^{\mathrm{fMet}}(\mathrm{Cy} 5)$ we obtained a rate of 30SIC formation essentially the same as that measured with IF2 ${ }^{\mathrm{Cy} 3}$ (Fig. 5), suggesting that fMettRNA $^{\mathrm{fMet}}(\mathrm{Cy} 5)$ is fully functional in formation of 30 SIC.

\section{Formation and translocation of a pretranslocation} (PRE) complex

Three samples of PRE complex made with mRNA-MFK programmed ribosomes were formed in parallel, by addition of: (1) both fMet-tRNA ${ }^{\text {fMet }}(\mathrm{Cy} 5)$ and Phe-tRNA ${ }^{\text {Phe }}$ (Cy3) (the donor-acceptor, or DA, sample); (2) unlabeled fMet-tRNA $^{\text {fMet }}$ and Phe-tRNA ${ }^{\text {Phe }}(\mathrm{Cy} 3)$ (the donor alone, or DU, sample); and (3) fMet-tRNA ${ }^{\text {fMet }}(\mathrm{Cy} 5)$ and unlabeled Phe-tRNA ${ }^{\text {Phe }}$ (the acceptor alone, or UA, sample). These complexes, which result in $\mathrm{fMetPhe}$ formation, were purified by ultracentrifugation through a sucrose cushion prior to their utilization in the fluorescence measurements described below. The stoichiometries of fMetPhe formed, and of $\left[{ }^{3} \mathrm{H}\right]$-Phe and $\left[{ }^{35} \mathrm{~S}\right]$-fMet cosedimenting with the ribosome in the PRE complexes (Table 1), are very similar whether using Cy3-labeled or unlabeled Phe-tRNA ${ }^{\text {Phe }}$ (DU

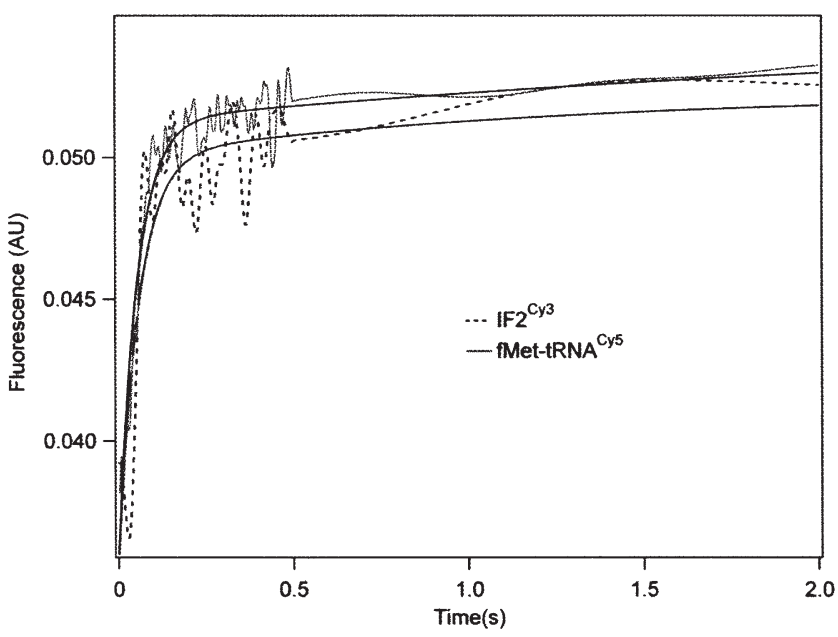

FIGURE 5. Rapid formation of 30SIC. Stopped-flow fluorescence measurements using limiting amounts of either IF2 ${ }^{\mathrm{Cy} 3}$ (prepared as described: H. Qin, C. Grigoriadou, and B.S. Cooperman, unpubl.) or fMet-tRNA ${ }^{\mathrm{fMet}}(\mathrm{Cy} 5)$, were carried out at $20^{\circ} \mathrm{C}$ with $0.3 \mu \mathrm{M} 30 \mathrm{~S}$ subunits and 3.0 equivalents of mRNA022, essentially as described (Grigoriadou et al. 2007b). For the IF2 ${ }^{\mathrm{Cy} 3}$ binding experiment, 0.5 equivalent of $\mathrm{IF}^{\mathrm{Cy}}{ }^{\mathrm{3}}$.GTP was rapidly mixed with a $30 \mathrm{~S}$ subunit solution containing 1.5 equivalents of IF1, IF3, and fMet-tRNA ${ }^{\text {fMet }}$. For the fMet-tRNA ${ }^{\mathrm{Met}}(\mathrm{Cy} 5)$ binding experiment, fMet-tRNA ${ }^{\mathrm{fMet}}(\mathrm{Cy} 5)$ (0.6 equivalent) was rapidly mixed with $30 \mathrm{~S}$ subunit solution containing 1.5 equivalents of IF1, IF2, and IF3. Both 30S-containing solutions were preincubated for $15 \mathrm{~min}$ at $37^{\circ} \mathrm{C}$ prior to rapid mixing. Excitation was at $530 \mathrm{~nm}$ or $650 \mathrm{~nm}$ and fluorescence was monitored through a bandpass filter $(550 \pm 10 \mathrm{~nm}$ or $680 \pm 10 \mathrm{~nm})$ for IF2 ${ }^{\mathrm{Cy} 3}$ or fMet-tRNA ${ }^{\mathrm{fMet}}(\mathrm{Cy} 5)$, respectively. Each trace was fit to a singleexponential equation, giving apparent rate constants of $21 \pm 2 \mathrm{sec}^{-1}$ $\left(\mathrm{IF} 2{ }^{\mathrm{Cy} 3}\right)$ and $19 \pm 1 \sec ^{-1}$ [fMet-tRNA $\left.{ }^{\mathrm{fMet}}(\mathrm{Cy} 5)\right]$. and DA samples versus UA sample) or Cy5-labeled or unlabeled fMet-tRNA ${ }^{\mathrm{fMet}}$ (UA and DA samples versus DU sample). These results provide a convincing demonstration of the functionality of the Cy-labeled tRNAs in binding to the ribosome and participating in dipeptide formation, as part of PRE complex formation.

Fluorescence spectra of the three PRE samples (Fig. 6A) provide clear evidence of FRET in the DA sample, as shown by the increase in acceptor and decrease in donor fluorescent intensities relative to the $\mathrm{A}$ and $\mathrm{D}$ samples, respectively. Addition of EF-G•GTP to each of the samples leading to post-translocation (POST) complex formation results in a marked decrease in FRET efficiency, as evidenced by the decreases in the differences observed comparing the DA sample with both the UA and DU samples (Fig. 6B). This decrease in FRET efficiency is consistent with an increase of $14 \AA$ in the distance between the dihydrouracil positions of $\mathrm{tRNA}^{\text {Phe }}$ and $\mathrm{tRNA}^{\mathrm{fMet}}$, calculated from coordinates determined by X-ray crystallographic analysis of ribosome-bound tRNAs (Yusupov et al. 2001), as these two tRNAs move from occupying the $\mathrm{A}$ - and $\mathrm{P}$-positions, respectively, in the PRE complex (28 ̊ apart), to occupying the P- and E-positions, respectively, in the POST complex (42 $\AA$ apart). As expected, movement to the E-site destabilizes tRNA ${ }^{\mathrm{fMet}}(\mathrm{Cy} 5)$ binding to the ribosome, as seen by the large reduction in Cy5 stoichiometry cosedimenting with ribosomes in the POST complex (Table 1). Addition to the three PRE samples of both EF-G•GTP and the next cognate ternary complex, EFTu•GTP•Lys-tRNA ${ }^{\text {Lys }}$, which should result in POST2 complex formation, placing fMetPheLys-tRNA ${ }^{\text {Lys }}$ in the P-site and $\mathrm{tRNA}^{\mathrm{Phe}}(\mathrm{Cy} 3)$ in the E-site (Fig. 6D), has the expected effects of reducing FRET efficiency to zero (Fig. 6C) and weakening tRNA ${ }^{\mathrm{Phe}}(\mathrm{Cy} 3)$ binding to the ribosome (Table 1).

\section{Kinetics of translocation}

The kinetics of FRET change during translocation to form the first POST complex on rapid mixing of EF-G•GTP with the PRE(DA), PRE(DU), or PRE(UA) complexes are displayed in Figure 7A,B. The changes shown for the DA sample include corrections for the significant decreases in fluorescence intensity of the DU sample on translocation and the much more minor changes in fluorescence intensity of the UA sample (Fig. 7C,D). The curve for the DA sample shows three phases (Fig. 7A,B): an initial lag phase $(\sim 0.00-0.07 \mathrm{sec})$, proceeding with little change in FRET efficiency $\left(k_{\text {app } 1}, 22 \pm 4 \sec ^{-1}\right)$, a second phase $(\sim 0.07-0.8$ sec) proceeding with a large decrease in FRET efficiency $\left(k_{\text {app2 }}, 4.9 \pm 0.6 \mathrm{sec}^{-1}\right)$, and a third, slower phase $(\sim 0.8-3$ $\mathrm{sec}$ ) proceeding with a slight additional decrease in FRET efficiency $\left(k_{\mathrm{app} 3}, 0.6 \pm 0.1 \mathrm{sec}^{-1}\right)$. Below we focus our attention on phases 1 and 2, as phase 3 likely reflects only slight additional tRNA movements following translocation and/or sample heterogeneity. 
TABLE 1. Stoichiometries for interaction of labeled tRNAs with the ribosome ${ }^{a}$

\begin{tabular}{|c|c|c|c|c|c|c|}
\hline & \multirow[b]{2}{*}{ fMetPhe formed } & \multicolumn{3}{|c|}{ Cosedimenting amino acid ${ }^{\mathrm{b}}$} & \multicolumn{2}{|c|}{ Cosedimenting dye $\mathrm{e}^{\mathrm{c}}$} \\
\hline & & $\mathrm{fMet} / 70 \mathrm{~S}$ & Phe/70S & Lys/70S & Cy5/70S & Су3/70S \\
\hline PRE (DU) & $0.55 \pm 0.03$ & $0.71 \pm 0.03$ & $0.78 \pm 0.06$ & - & - & $0.75 \pm 0.02$ \\
\hline PRE (UA) & $0.48 \pm 0.04$ & $0.64 \pm 0.05$ & $0.63 \pm 0.05$ & - & $0.63 \pm 0.02$ & - \\
\hline PRE (DA) & $0.54 \pm 0.03$ & $0.74 \pm 0.03$ & $0.68 \pm 0.04$ & - & $0.61 \pm 0.04$ & $0.71 \pm 0.03$ \\
\hline POST (DA) & ND & $0.62 \pm 0.03$ & $0.64 \pm 0.04$ & - & $0.21 \pm 0.02$ & $0.70 \pm 0.03$ \\
\hline POST2 (DA) & ND & $0.63 \pm 0.03$ & $0.58 \pm 0.04$ & $0.57 \pm 0.05$ & $0.13 \pm 0.02^{d}$ & $0.05 \pm 0.02$ \\
\hline
\end{tabular}

ND indicates not determined.

${ }^{\mathrm{a}}$ Numbers given are stoichiometries per $70 \mathrm{~S}$ ribosome. Cosedimentation values are for samples that were centrifuged through a $1.1 \mathrm{M}$ sucrose cushion $\left(450,000 \mathrm{~g}, 40 \mathrm{~min}, 4^{\circ} \mathrm{C}\right)$.

${ }^{\mathrm{b}} \mathrm{Amino}$ acids were radioactively labeled: ${ }^{35} \mathrm{~S}$-fMet; ${ }^{3} \mathrm{H}$-Phe; ${ }^{14} \mathrm{C}$-Lys.

${ }^{c}$ Estimated by dye absorbance: Cy $5 \varepsilon_{650 \mathrm{~nm}}=250,000 \mathrm{M}^{-1} \mathrm{~cm}^{-1}$ (Amersham); Cy3 $\varepsilon_{550 \mathrm{~nm}}=150,000 \mathrm{M}^{-1} \mathrm{~cm}^{-1}$ (Amersham).

${ }^{\mathrm{d}}$ This nonzero value most likely represents a fraction of the fMet-tRNA ${ }^{\mathrm{fMet}}$ (Cy5) preparation which binds to the ribosome in the P-site but does not enter into PRE complex.

Previously, in work using either a proflavin-labeled derivative of $\mathrm{tRNA}^{\mathrm{fMet}}$ and unlabeled fMetPhe-tRNA ${ }^{\text {Phe }}$ or a proflavin-labeled derivative of fMetPhe-tRNA ${ }^{\text {Phe }}$ and unlabeled tRNA ${ }^{\mathrm{fMet}}$, we showed that translocation proceeds via a two-phase reaction, in which the first phase of reaction corresponds to conversion of the pretranslocation (PRE) complex to an intermediate (INT) complex, and the second phase corresponds to INT conversion to the postranslocation (POST) complex (Pan et al. 2007). The values of $k_{\mathrm{app} 1}$ and $k_{\text {app2 }}$ determined in this work are virtually identical to those we found in Pan et al. (2007) for INT formation and disappearance, demonstrating the functionality of Cy-labeled derivatives in translocation.

Furthermore, the large decrease in FRET efficiency found in phase 2 (Fig. $7 \mathrm{~A}, \mathrm{~B})$ strongly suggests that, during translocation, the large increase in the distance between the tertiary core regions of the two tRNAs, to which the Cy dyes are attached, occurs during INT to POST complex conversion, whereas PRE to INT complex formation (phase 1), which involves little change in FRET efficiency, occurs with little change in this distance. This suggestion is consistent with the hypothesis that INT complex formation from PRE complex primarily involves movements of the flexible $3^{\prime}$-single-stranded regions of the tRNAs, whereas INT to POST conversion requires more considerable movement of the tRNA core structures.
In Pan et al. (2007) we presented evidence that (1) conversion of PRE to INT complex results in both tRNAs adopting hybrid orientations, with $\mathrm{tRNA}^{\mathrm{fMet}}$ in a $\mathrm{P} / \mathrm{E}$ site and fMetPhe-tRNA ${ }^{\text {Phe }}$ in an A/P site; (2) the translocation
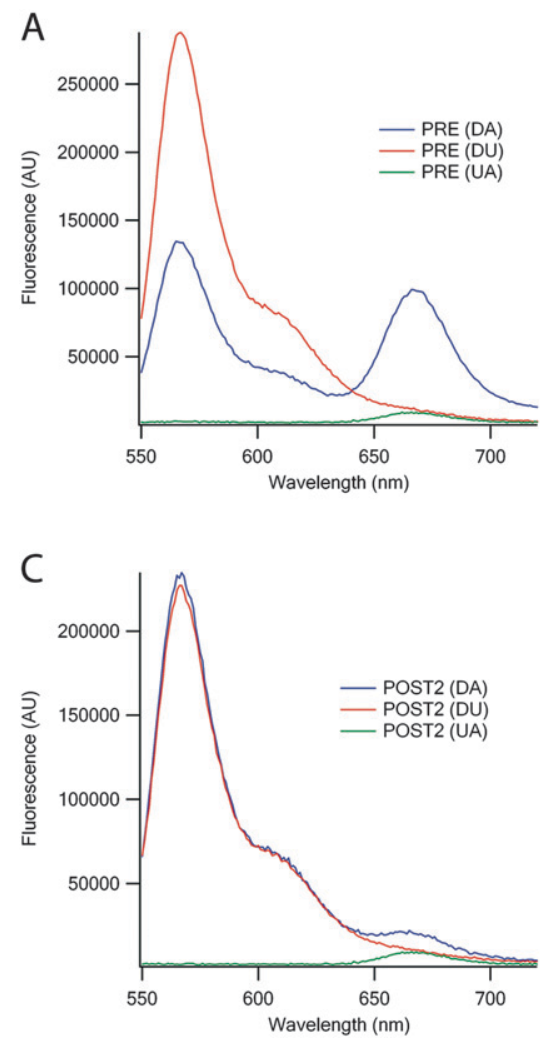

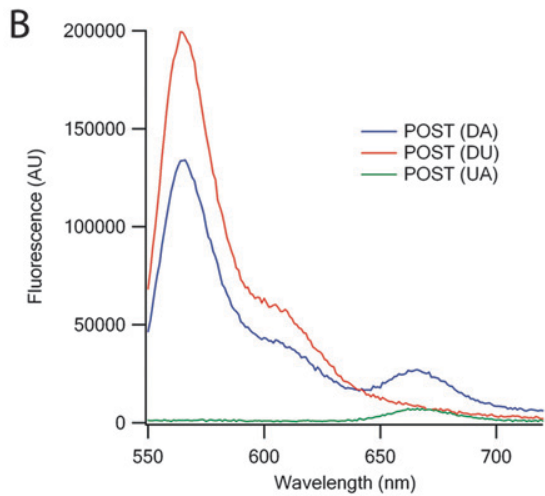

D
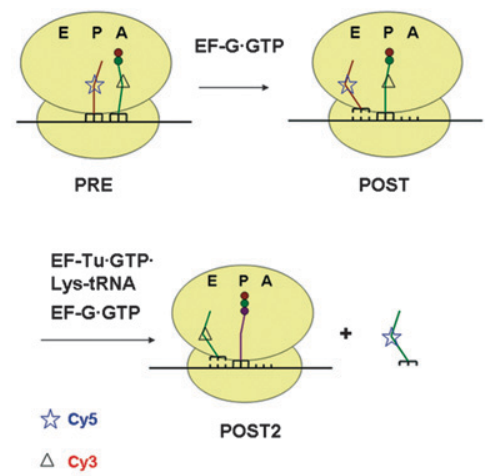

FIGURE 6. Fluorescence spectra of PRE $(A)$, POST $(B)$, and POST2 $(C)$ complexes. DA, Phe-tRNA ${ }^{\text {Phe }}(\mathrm{Cy} 3)+\mathrm{fMet}^{-\mathrm{tRNA}}{ }^{\mathrm{fMet}}(\mathrm{Cy} 5)$; DU, Phe-tRNA ${ }^{\text {Phe }}(\mathrm{Cy} 3)+\mathrm{fMet}^{\mathrm{tRNA}}{ }^{\mathrm{fMet}}$; and UA, Phe-tRNA ${ }^{\text {Phe }}+$ fMet-tRNA $^{\text {fMet }}($ Cy5). (A) PRE complexes $(0.1 \mu \mathrm{M}$ in Buffer C); (B) POST complexes formed by mixing PRE complexes with $0.5 \mu \mathrm{M}$ EF-G and $1 \mathrm{mM}$ GTP; $(C)$ POST2 complexes formed by mixing PRE complexes with $0.5 \mu \mathrm{M}$ EF-G, $1 \mathrm{mM}$ GTP, $0.3 \mu \mathrm{M}$ LystRNA ${ }^{\text {Lys }}$, and $0.5 \mu \mathrm{M}$ EF-Tu. All mixtures were incubated at $25^{\circ} \mathrm{C}$ for at least 3 min prior to recording spectra. Each spectrum is an average of three traces. All concentrations are final. 
A

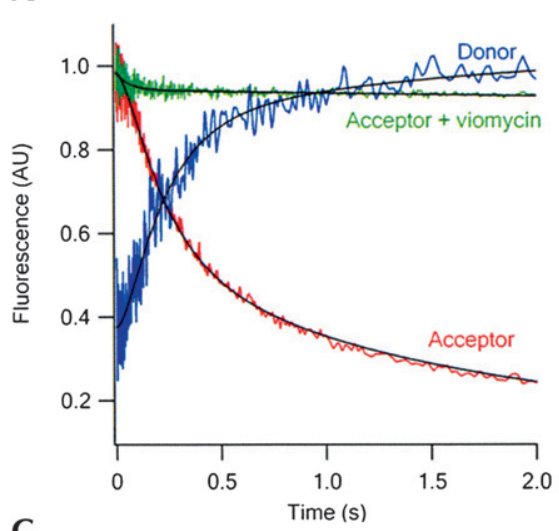

C

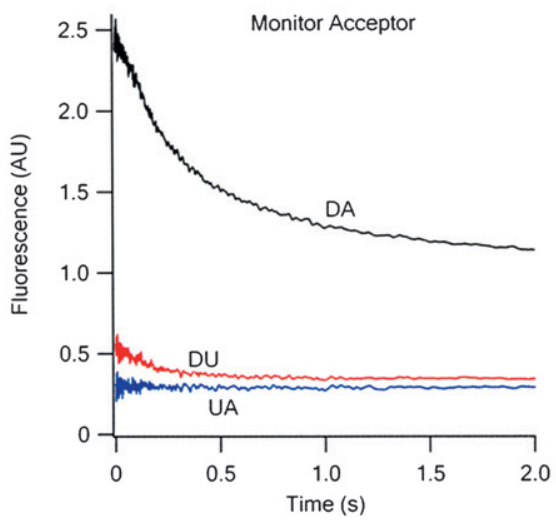

B

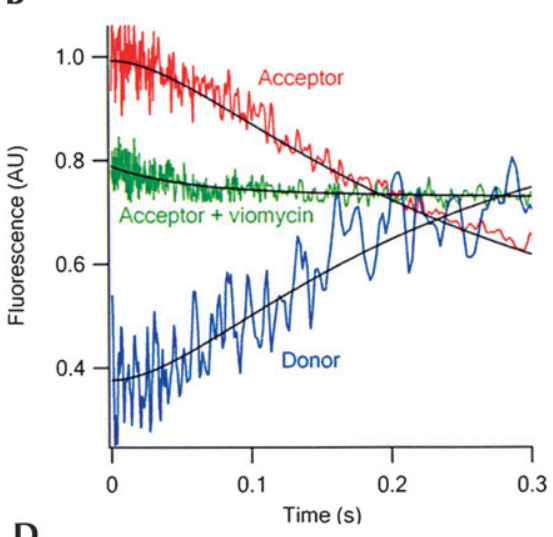

D

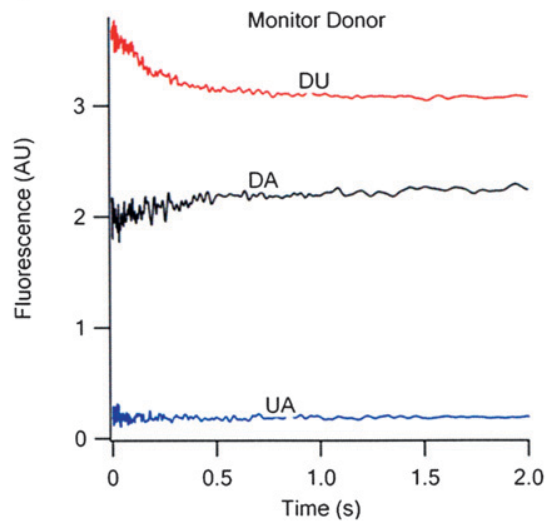

FIGURE 7. Time courses of FRET change during translocation. (A) PRE complex $(0.1 \mu \mathrm{M}$, after mixing) containing fMetPhe-tRNA ${ }^{\mathrm{Phe}}(\mathrm{Cy} 3)$ in the A-site and $\mathrm{tRNA}^{\mathrm{fMet}}(\mathrm{Cy} 5)$ in the P-site (DA sample) was rapidly mixed with EF-G•GTP $\left(2 \mu \mathrm{M}\right.$, after mixing) in buffer A at $25^{\circ} \mathrm{C}$, with excitation at $518 \mathrm{~nm}$. Parallel experiments were carried out with the DU [Phe-tRNA ${ }^{\text {Phe }}$ $\left.(\mathrm{Cy} 3)+\mathrm{fMet}^{-\mathrm{tRNA}}{ }^{\mathrm{fMet}}\right]$ and UA [Phe-tRNA $\left.{ }^{\text {Phe }}+\mathrm{fMet}-\mathrm{RNA}^{\mathrm{fMet}}(\mathrm{Cy} 5)\right]$ samples. The red and blue traces are for fluorescence intensities monitored at acceptor wavelength $(680 \pm 10 \mathrm{~nm})$ and donor wavelength $(570 \pm 10 \mathrm{~nm})$, respectively. The traces shown are corrected for contributions to fluorescence change from the donor alone and acceptor alone traces at both 680 $\mathrm{nm}(C)$ and $570 \mathrm{~nm}(D)$. For acceptor, the corrected trace is equal to DA-(DU+UA). For donor, the corrected trace is equal to (DA-UA)/DU. Both traces were globally fit to a threestep model, I $\rightarrow$ II $\rightarrow$ III $\rightarrow$ IV, in which the acceptor fluorescence intensity of I and of II are essentially equal, and the large decrease in FRET signal is associated with II to III conversion. The green trace measures the acceptor fluorescence intensity when PRE complex was preincubated with viomycin $(100 \mu \mathrm{M})$ for $1 \mathrm{~min}$ at $37^{\circ} \mathrm{C}$ before mixing with EF-G•GTP. (B) Same as $(A)$, with expanded time scale. The green trace in the presence of viomycin has been offset for clarity. (C) Fluorescence change during translocation monitoring acceptor at $680 \pm 10 \mathrm{~nm}$. $(D)$ Fluorescence change during translocation monitoring donor at $570 \pm 10 \mathrm{~nm}$.

inhibitor viomycin stabilized an intermediate between the PRE and INT complexes, denoted the P/E complex, in which tRNA $^{\text {fMet }}$ moved into a $\mathrm{P} / \mathrm{E}$ hybrid site, while fMetPhe-tRNA ${ }^{\text {Phe }}$ was forced to remain in the A-site; and (3) the apparent rate constant for formation of the P/E complex was similar to the rate constant for INT formation in the absence of viomycin. The results in Figure 7, A and $\mathrm{B}$, are consistent with this interpretation, since viomycin prevents the large decrease in FRET efficiency characteristic of INT to POST complex conversion, permitting only a minor decrease in FRET efficiency (Fig. 7B), which pro- ceeds with an apparent rate constant $\left(16 \pm 2 \mathrm{sec}^{-1}\right)$ similar to $k_{\mathrm{app} 1}$ in the absence of viomycin.

Poly $(U)$ dependent poly(Phe) synthesis

Poly(Phe) synthesis by poly(U)-programmed ribosomes was conducted in parallel with both unlabeled Phe-tRNA ${ }^{\text {Phe }}$ and PhetRNA $^{\text {Phe }}(\mathrm{Cy} 3)$. The results obtained (Fig. 8) that both tRNAs have similar activity during the initial, rapid phase of reaction, although the labeled tRNA is less active in the slower second phase of reaction, possibly due, at least in part, to the decreased aminoacylation efficiency of Cy3-labeled tRNA ${ }^{\text {Phe }}$ (see above).

\section{Conclusion}

We have developed a method of replacing $\mathrm{D}$ residues in tRNAs with $\mathrm{Cy} 3$ and Cy5 dyes linked to a hydrazide group, demonstrated that the labeled molecules are functional in aminoacylation, 30SIC formation, codon-dependent binding to the ribosome, translocation, and polypeptide synthesis, and used the results of a rapid turnover FRET experiment to gain a new insight regarding the mechanism of translocation. This method should be straightforwardly generalizable to the incorporation into tRNA or other D-containing RNAs of other hydrazide-linked fluorophores.

\section{MATERIALS AND METHODS}

\section{Standard materials}

Tight-coupled ribosomes from E. coli MRE600 cells, mRNA022, unlabeled fMettRNA $^{\text {fMet }}$ and Phe-tRNA ${ }^{\text {Phe }}$, cloned E. coli His-tagged proteins EF-G, EF-Tu, IF1, IF2, and IF3, 70 S initiation complex (70SIC), aminoacyl-tRNA•EFTu•GTP ternary complexes and PRE complex were prepared as described (Pan et al. 2008). mRNA-MFK was ordered from Dharmacon with the following sequence: GGGAAGGAGGUAA AAAUGUUUAAACGUAAAUCUACU (initiator codon underlined). E. coli tRNA ${ }^{\mathrm{fMet}}$, $\mathrm{tRNA}^{\mathrm{Lys}}$, and yeast $\mathrm{tRNA}{ }^{\text {Phe }}$ were obtained from Chemical Block (Moscow).

\section{Yeast Phe-tRNA ${ }^{\text {Phe }}($ Cy3) preparation}

Reduction of $\mathrm{tRNA}^{\text {Phe }}$ to form $\mathrm{tRNA}^{\mathrm{Phe}}$ (red) was carried out by incubating tRNA ${ }^{\text {Phe }}(2.5 \mathrm{mg} / \mathrm{mL}), \mathrm{NaBH}_{4}(10 \mathrm{mg} / \mathrm{mL}$, added from 


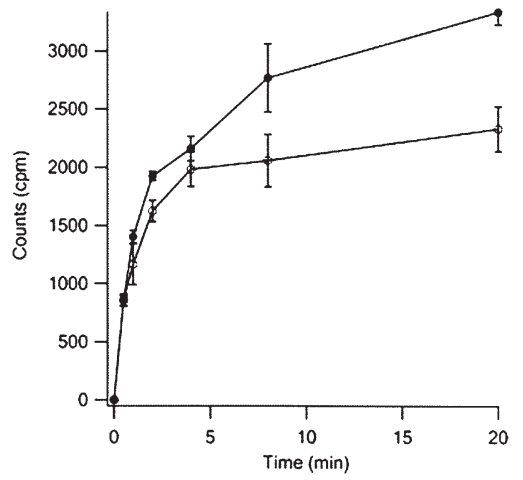

FIGURE 8. Comparison of Phe-tRNA ${ }^{\text {Phe }}$ and Phe-tRNA ${ }^{\text {Phe }}(\mathrm{Cy} 3)$ in the poly(Phe) assay. The poly(Phe) assay was carried out as described in Materials and Methods. Each point is the average of two independent experiments.

$100 \mathrm{mg} / \mathrm{mL}$ in $10 \mathrm{mM} \mathrm{KOH})$ in $40 \mathrm{mM}$ Tris- $\mathrm{HCl}(\mathrm{pH} \mathrm{7.5)}$ at $0^{\circ} \mathrm{C}$ for $60 \mathrm{~min}$, in a total volume of $400 \mu \mathrm{L}$. Three ethanol precipitations of $\mathrm{tRNA}^{\mathrm{Phe}}$ (red) was used to remove unreacted $\mathrm{NaBH}_{4} \cdot \mathrm{tRNA}^{\text {Phe }}$ (red) was charged with $\left[{ }^{3} \mathrm{H}\right]$-Phe as described earlier for yeast tRNA ${ }^{\text {Phe }}$ (Pan et al. 2007). Phe-tRNA ${ }^{\text {Phe }}$ (red) was resolved from uncharged $\mathrm{tRNA}^{\text {Phe }}$ (red) by purification using phenyl RP-HPLC $(4.6 \times 250 \mathrm{~mm}$, Alltech $)$, with a gradient of $0 \%-24 \%$ methanol in $20 \mathrm{mM} \mathrm{NH}_{4} \mathrm{Ac}(\mathrm{pH} 5.5)$ and $50 \mathrm{mM}$ $\mathrm{NaCl}$. The pooled fractions were lyophilized, dissolved in water, and ethanol precipitated prior to labeling. Cy3 labeling was carried out by dissolving dried Phe-tRNA ${ }^{\text {Phe }}$ (red) $(72 \mathrm{nmol})$ in $40 \mu \mathrm{L}$ of $0.1 \mathrm{M}$ sodium formate ( $\mathrm{pH} 3.7$ ) and mixed with $10 \mu \mathrm{L}$ of a DMSO solution of Cy3-hydrazide $(200 \mathrm{mM})$. Incubation at $37^{\circ} \mathrm{C}$ for $2 \mathrm{~h}$ was followed by vacuum drying. The dried sample was dissolved in $400 \mu \mathrm{L}$ of $50 \mathrm{mM}$ sodium acetate at $\mathrm{pH} 6.0$, and unbound dye was removed by extraction with buffer-saturated phenol, and two rounds of ethanol precipitation. Purification of Cy3-labeled Phe-tRNA ${ }^{\text {Phe }}$ (red), denoted Phe-tRNA ${ }^{\text {Phe }}(\mathrm{Cy} 3)$, from unlabeled Phe-tRNA ${ }^{\text {Phe }}$ (red) was carried out by FPLC using a MonoQ column with a gradient of $0.5-0.9 \mathrm{M} \mathrm{NaCl}$ in $50 \mathrm{mM}$ $\mathrm{NaAc}\left(\mathrm{pH}\right.$ 6.0). Eluted Phe-tRNA ${ }^{\mathrm{Phe}}(\mathrm{Cy} 3)$ was precipitated by addition of 2.5 volume of $-20^{\circ} \mathrm{C}$ ethanol with standing $-80^{\circ} \mathrm{C}$ for $30 \mathrm{~min}$. Following centrifugation, the precipitate was dissolved in water and stored at $-80^{\circ} \mathrm{C}$.

\section{E. coli fMet-tRNA ${ }^{\text {fMet }}(\mathrm{Cy} 5)$ preparation}

tRNA $^{\text {fMet }}$ was reduced and labeled with Cy5-hydrazide using procedures essentially identical to those described above. The resulting Cy5-labeled tRNA ${ }^{\mathrm{fMet}}$ (red) was charged and formylated as described for unlabeled tRNA ${ }^{\mathrm{fMet}}$ (Pan et al. 2008), and purified by FPLC using a MonoQ column as described above.

\section{E. coli Lys-tRNA ${ }^{\text {Lys }}$ preparation}

tRNA ${ }^{\text {Lys }}$ was charged with pure His-tagged E. coli Lys-RS, purified on a Ni-NTA (Qiagen) column, by incubating $20 \mu \mathrm{M}$ tRNA ${ }^{\text {Lys }}$, $80 \mu \mathrm{M}\left[{ }^{14} \mathrm{C}\right]$ lysine, and $1 \mu \mathrm{M}$ Lys-RS in $100 \mathrm{mM}$ Tris- $\mathrm{HCl}$ (pH 7.8), 4 mM ATP, $20 \mathrm{mM} \mathrm{MgCl} 2,1 \mathrm{mM}$ EDTA, and $7 \mathrm{mM} 2-$ mercaptoethanol at $37^{\circ} \mathrm{C}$ for $10 \mathrm{~min}$. Purification of Lys-tRNA ${ }^{\text {Lys }}$ was carried out on FPLC using a MonoQ column with a gradient of $0-1 \mathrm{M} \mathrm{NaCl}$ in $50 \mathrm{mM} \mathrm{Na}$ acetate ( $\mathrm{pH} 5.0$ ) yielding a sample charged to a level of $1030 \mathrm{pmol}$ Lys/ $\mathrm{A}_{260}$.

\section{Complex formation}

70SIC was formed by incubating $2 \mu \mathrm{M}$ 70S ribosome, $8 \mu \mathrm{M}$ mRNA-MFK, $3 \mu \mathrm{M}$ each of IF1, IF2, IF3, and fMet-tRNA ${ }^{\text {fMet }}$, and $1 \mathrm{mM}$ GTP in Buffer A (50 mM Tris- $\mathrm{HCl}$ [pH 7.5], $70 \mathrm{mM}$ $\mathrm{NH}_{4} \mathrm{Cl}, 30 \mathrm{mM} \mathrm{KCl}, 7 \mathrm{mM} \mathrm{MgCl}, 1 \mathrm{mM} \mathrm{DTT}$ ) for $25 \mathrm{~min}$ at $37^{\circ} \mathrm{C}$. TC was formed by incubating $6 \mathrm{EF}-\mathrm{Tu}, 3 \mu \mathrm{M}$ Phe-tRNA ${ }^{\mathrm{Phe}}$, $1 \mathrm{mM}$ GTP, $1.5 \mathrm{mM}$ phosphoenolpyruvate, and $0.5 \mathrm{mg} / \mathrm{L}$ pyruvate kinase in buffer A for $5 \mathrm{~min}$ at $37^{\circ} \mathrm{C}$. PRE complex was formed by incubating $1 \mu \mathrm{M}$ 70SIC with $1.5 \mu \mathrm{M}$ TC for 0.5 $\min$ at $37^{\circ} \mathrm{C}$, and purified by centrifugation through a $1.1 \mathrm{M}$ sucrose cushion $\left(450,000 \mathrm{~g}, 40 \mathrm{~min}, 4^{\circ} \mathrm{C}\right.$ ) in Buffer B (same as buffer A but with $20 \mathrm{mM} \mathrm{MgCl} 2$ ). The pellet was resuspended in buffer C (20 mM HEPES-KOH [pH 7.6 at $\left.0^{\circ} \mathrm{C}\right], 4.5 \mathrm{mM} \mathrm{MgAc}_{2}$, $4 \mathrm{mM}$ 2-mercaptoethanol, $150 \mathrm{mM} \mathrm{NH}_{4} \mathrm{Ac}, 0.05 \mathrm{mM}$ spermine, and $2 \mathrm{mM}$ spermidine) to a concentration of about $5 \mu \mathrm{M}$, and stored in the $-80^{\circ} \mathrm{C}$ freezer before being used.

\section{Fluorescence measurements}

Steady-state fluorescence spectra were measured on a Fluorolog-3 spectrofluorometer (Horiba Jobin Yvon) with an excitation wavelength of $518 \mathrm{~nm}$. Changes in fluorescence following rapid mixing were carried out using an SX.18MV stopped-flow spectrofluorometer (Applied Photophysics).

\section{fMetPhe formation assay}

The fMetPhe formation assay was carried out as described (Pan et al. 2008).

\section{Poly(Phe) assay}

The poly(Phe) assay was carried out in buffer D (20 mM Tris- $\mathrm{HCl}$ [pH 7.6], $200 \mathrm{mM} \mathrm{NH}_{4} \mathrm{Cl}, 10 \mathrm{mM} \mathrm{MgAc}_{2}$ ). All concentrations given below are for the final reaction solution after EF$\mathrm{Tu}$ addition. Initiation complex was formed by mixing poly(U) $(0.3 \mu \mathrm{g} / \mu \mathrm{L}), 70 \mathrm{~S}$ ribosomes $(0.3 \mu \mathrm{M})$, and $\left[{ }^{3} \mathrm{H}\right]$-AcPhe-tRNA ${ }^{\text {Phe }}$ $(0.36 \mu \mathrm{M})$ at $37^{\circ} \mathrm{C}$ for $5 \mathrm{~min}$. 2-Mercaptoethanol $(2.8 \mathrm{mM})$, pyruvate kinase $(2.8 \mu \mathrm{M})$, phosphoenol pyruvate $(0.5 \mathrm{mM})$, GTP (0.6 mM), EF-G $(0.6 \mu \mathrm{M})$, and $\left[{ }^{3} \mathrm{H}\right]$-Phe-tRNA ${ }^{\text {Phe }}$ (4 $\mu \mathrm{M}$-Cy3 labeled or unlabeled) were next added, and reaction was initiated at $37^{\circ} \mathrm{C}$ by addition of EF-Tu $(0.6 \mu \mathrm{M})$. The total reaction volume was $50 \mu \mathrm{L}$. Aliquots were removed at various times, added to $0.3 \mathrm{~mL} 5 \% \mathrm{TCA}$, heated to $95^{\circ} \mathrm{C}$ for $15 \mathrm{~min}$, cooled on ice, filtered through a nitrocellulose filter with $5 \times 1 \mathrm{~mL}$ washes with $5 \%$ cold TCA, and radioactivity was determined. The background was set equal to the radioactivity measured prior to EF-Tu addition.

\section{POTENTIAL CONFLICT OF INTEREST DISCLOSURE}

B.S.C. is a consultant to Anima Cell Metrology and owns shares in the company. 


\section{ACKNOWLEDGMENTS}

This work is supported by grants from Anima Cell Metrology and NIH (GM071014). We thank Ya-Ming Hou for providing us with the plasmid for His-tagged E. coli Lys-RS.

Received July 7, 2008; accepted October 24, 2008.

\section{REFERENCES}

Betteridge, T., Liu, H., Gamper, H., Kirillov, S., Cooperman, B.S., and Hou, Y.M. 2007. Fluorescent labeling of tRNAs for dynamics experiments. RNA 13: 1594-1601.

Bieling, P., Beringer, M., Adio, S., and Rodnina, M.V. 2006. Peptide bond formation does not involve acid-base catalysis by ribosomal residues. Nat. Struct. Mol. Biol. 13: 423-428.

Blanchard, S.C., Gonzalez, R.L., Kim, H.D., Chu, S., and Puglisi, J.D. 2004a. tRNA selection and kinetic proofreading in translation. Nat. Struct. Mol. Biol. 11: 1008-1014.

Blanchard, S.C., Kim, H.D., Gonzalez Jr., R.L., Puglisi, J.D., and Chu, S. 2004b. tRNA dynamics on the ribosome during translation. Proc. Natl. Acad. Sci. 101: 12893-12898.

Cerutti, P. and Miller, N. 1967. Selective reduction of yeast transfer ribonucleic acid with sodium borohydride. J. Mol. Biol. 26: $55-66$.

Cordes, E.H. and Jencks, W.P. 1962. On the mechanism of Schiff base formation and hydrolysis. J. Am. Chem. Soc. 84: 832-837.

Fei, J., Kosuri, P., MacDougall, D.D., and Gonzalez Jr., R.L. 2008. Coupling of ribosomal L1 stalk and tRNA dynamics during translation elongation. Mol. Cell 30: 348-359.

Grigoriadou, C., Marzi, S., Kirillov, S., Gualerzi, C.O., and Cooperman, B.S. 2007a. A quantitative kinetic scheme for $70 \mathrm{~S}$ translation initiation complex formation. J. Mol. Biol. 373: 562-572.

Grigoriadou, C., Marzi, S., Pan, D., Gualerzi, C.O., and Cooperman, B.S. 2007b. The translational fidelity function of IF3 during transition from the $30 \mathrm{~S}$ initiation complex to the $70 \mathrm{~S}$ initiation complex. J. Mol. Biol. 373: 551-561.

Jencks, W.P. 1964. Mechanism and catalysis of simple carbonyl group reactions. Prog. Phys. Org. Chem. 2: 63-128.

Kothe, U. and Rodnina, M.V. 2007. Codon reading by tRNA ${ }^{\mathrm{Ala}}$ with modified uridine in the wobble position. Mol. Cell 25: 167-174.

Lee, T.H., Blanchard, S.C., Kim, H.D., Puglisi, J.D., and Chu, S. 2007. The role of fluctuations in tRNA selection by the ribosome. Proc. Natl. Acad. Sci. 104: 13661-13665.

Levrand, B., Fieber, W., Lehn, J.-M., and Herrmann, A. 2007. Controlled release of volatile aldehydes and ketones from dynamic mixtures generated by reversible hydrazone formation. Helv. Chim. Acta 90: 2281-2314.

McIntosh, B., Ramachandiran, V., Kramer, G., and Hardesty, B. 2000. Initiation of protein synthesis with fluorophore-Met-tRNA ${ }^{\mathrm{f}}$ and the involvement of IF-2. Biochimie 82: 167-174.
Munro, J.B., Altman, R.B., O’Connor, N., and Blanchard, S.C. 2007. Identification of two distinct hybrid state intermediates on the ribosome. Mol. Cell 25: 505-517.

Pan, D., Kirillov, S., Zhang, C.M., Hou, Y.M., and Cooperman, B.S. 2006. Rapid ribosomal translocation depends on the conserved 1855 base pair in P-site transfer RNA. Nat. Struct. Mol. Biol. 13: 354359.

Pan, D., Kirillov, S.V., and Cooperman, B.S. 2007. Kinetically competent intermediates in the translocation step of protein synthesis. Mol. Cell 25: 519-529.

Pan, D., Zhang, C.M., Kirillov, S., Hou, Y.M., and Cooperman, B.S. 2008. Perturbation of the tRNA tertiary core differentially affects specific steps of the elongation cycle. J. Biol. Chem. 283: 18431-18440.

Pape, T., Wintermeyer, W., and Rodnina, M.V. 1998. Complete kinetic mechanism of elongation factor Tu-dependent binding of aminoacyl-tRNA to the A site of the E. coli ribosome. EMBO J. 17: 7490-7497.

Rodnina, M.V., Fricke, R., and Wintermeyer, W. 1994. Transient conformational states of aminoacyl-tRNA during ribosome binding catalyzed by elongation factor Tu. Biochemistry 33: 12267-12275.

Rodnina, M.V., Savelsbergh, A., Katunin, V.I., and Wintermeyer, W. 1997. Hydrolysis of GTP by elongation factor G drives tRNA movement on the ribosome. Nature 385: 37-41.

Savelsbergh, A., Katunin, V.I., Mohr, D., Peske, F., Rodnina, M.V., and Wintermeyer, W. 2003. An elongation factor G-induced ribosome rearrangement precedes tRNA-mRNA translocation. Mol. Cell 11: 1517-1523.

Schleich, H.G., Wintermeyer, W., and Zachau, H.G. 1978. Replacement of wybutine by hydrazines and its effect on the active conformation of yeast tRNA ${ }^{\text {Phe }}$. Nucleic Acids Res. 5: 1701-1713.

Thiebe, R. and Zachau, H.G. 1968. A specific modification next to the anticodon of phenylalanine transfer ribonucleic acid. Eur. J. Biochem. 5: 546-555.

Wintermeyer, W. and Zachau, H.G. 1971. Replacement of Y base, dihydrouracil, and 7-methylguanine in tRNA by artificial odd bases. FEBS Lett. 18: 214-218.

Wintermeyer, W. and Zachau, H.G. 1974. Replacement of odd bases in tRNA by fluorescent dyes. Methods Enzymol. 29: 667-673.

Wintermeyer, W. and Zachau, H.G. 1979. Fluorescent derivatives of yeast tRNA ${ }^{\text {Phe }}$. Eur. J. Biochem. 98: 465-475.

Wintermeyer, W., Schleich, H.G., and Zachau, H.G. 1979. Incorporation of amines or hydrazines into tRNA replacing wybutine or dihydrouracil. Methods Enzymol. 59: 110-121.

Woolhead, C.A., McCormick, P.J., and Johnson, A.E. 2004. Nascent membrane and secretory proteins differ in FRET-detected folding far inside the ribosome and in their exposure to ribosomal proteins. Cell 116: 725-736.

Yang, C.H. and Söll, D. 1974. Studies of transfer RNA tertiary structure of singlet-singlet energy transfer. Proc. Natl. Acad. Sci. 71: 2838-2842.

Yusupov, M.M., Yusupova, G.Z., Baucom, A., Lieberman, K., Earnest, T.N., Cate, J.H., and Noller, H.F. 2001. Crystal structure of the ribosome at $5.5 \AA$ resolution. Science 292: 883-896. 

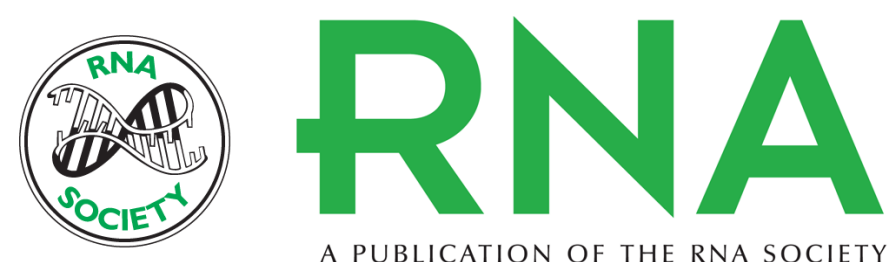

A PUBLICATION OF THE RNA SOCIETY

\section{Synthesis and functional activity of tRNAs labeled with fluorescent hydrazides in the D-loop}

Dongli Pan, Haiou Qin and Barry S Cooperman

RNA 2009 15: 346-354 originally published online December 31, 2008

Access the most recent version at doi:10.1261/rna.1257509

$\begin{array}{ll}\text { References } & \begin{array}{l}\text { This article cites } 31 \text { articles, } 7 \text { of which can be accessed free at: } \\ \text { http://rnajournal.cshlp.org/content/15/2/346.full.html\#ref-list-1 }\end{array}\end{array}$

License

Email Alerting Receive free email alerts when new articles cite this article - sign up in the box at the Service top right corner of the article or click here.

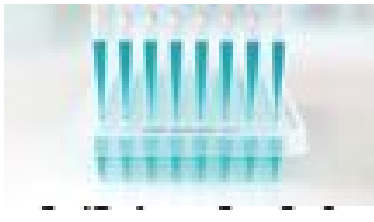

Providing Precise Solutions for your research.

To subscribe to RNA go to:

http://rnajournal.cshlp.org/subscriptions 